\title{
Derivation of Guidelines for Uranium Residual Radioactive Material in Soil at the New Brunswick Site, Middlesex County, New Jersey
}

by D. Dunning, S. Kamboj, M. Nimmagadda, and C. Yu

Environmental Assessment Division,

Argonne National Laboratory, 9700 South Cass Avenue, Argonne, Illinois 60439

February 1996

Work sponsored by United States Department of Energy, Office of Environmental Restoration, Washington, D.C., and Oak Ridge Operations Office, Formerly Utilized Sites Remedial Action Program, Oak Ridge, Tennessee

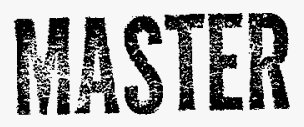


This report is printed on recycled paper. 


\section{DISCLAMMER}

Portions of this document may be illegible in electronic image products. Images are produced from the best available original document. 


\section{CONTENTS}

NOTATION

SUMMARY

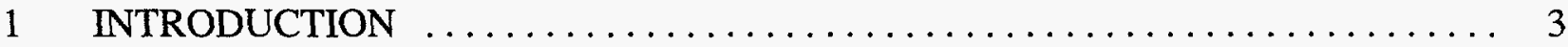

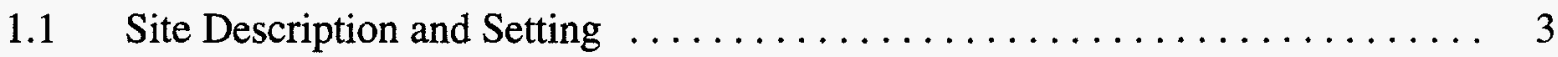

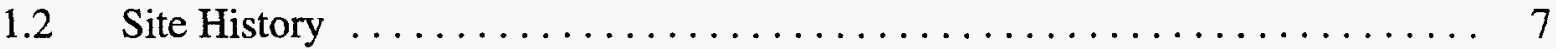

1.3 Derivation of Cleanup Guidelines $\ldots \ldots \ldots \ldots \ldots \ldots \ldots \ldots \ldots \ldots$

2 SCENARIO DEFINITIONS $\ldots \ldots \ldots \ldots \ldots \ldots \ldots \ldots \ldots \ldots \ldots \ldots \ldots \ldots$

3 DOSE/SOURCE CONCENTRATION RATIOS ...................... 14

4 RESIDUAL RADIOACTIVE MATERIAL GUIDELINES $\ldots \ldots \ldots \ldots \ldots \ldots \ldots$

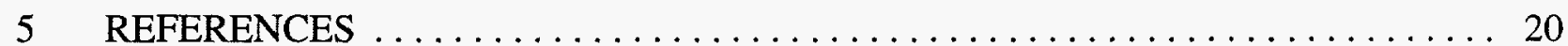

APPENDIX: Scenarios and Parameters Used for the Analysis of the NBS . . . . . . . . 21

\section{FIGURES}

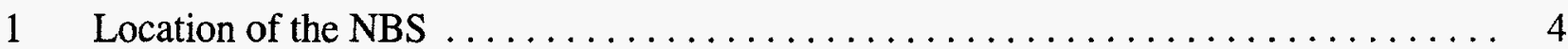

2 Plan View of the NBS before Decommissioning and Decontamination $\ldots \ldots \ldots \ldots$. 5

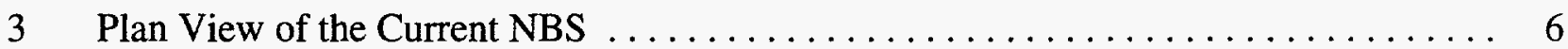

\section{TABLES}

1 Summary of Pathways Considered for Scenarios A, B, and C at the NBS $\ldots \ldots \ldots 13$

2 Maximum Dose/Source Concentration Ratios for Scenario A at the NBS ......... 15

3 Maximum Dose/Source Concentration Ratios for Scenario B at the NBS . . . . . . . 15 


\section{TABLES (Cont.)}

4 Maximum Dose/Source Concentration Ratios for Scenario C at the NBS 


\section{NOTATION}

The following is a list of the acronyms, initialisms, and abbreviations (including units of measure) used in this document. Some acronyms used only in tables or equations are defined in the respective tables or equations.

\section{ACRONYMS, INITIALISMS, AND ABBREVIATIONS}

AEC U.S. Atomic Energy Commission

ALARA as low as reasonably achievable

ANL Argonne National Laboratory

BNI Bechtel National, Inc.

CFR Code of Federal Regulations

DOE U.S. Department of Energy

FUSRAP Formerly Utilized Sites Remedial Action Program

NBS New Brunswick Site

RESRAD residual radioactive material guideline computer code

\section{UNITS OF MEASURE}

$\begin{array}{ll}{ }^{\circ} \mathrm{C} & \text { degree(s) Celsius } \\ \mathrm{cm} & \text { centimeter(s) } \\ \mathrm{cm}^{3} & \text { cubic centimeter(s) } \\ \mathrm{d} & \text { day(s) } \\ { }^{\circ} \mathrm{F} & \text { degree(s) Fahrenheit } \\ \mathrm{g} & \text { gram(s) } \\ \mathrm{h} & \text { hour(s) } \\ \mathrm{ha} & \text { hectare(s) } \\ \mathrm{in} . & \text { inch(es) } \\ \mathrm{kg} & \text { kilogram(s) } \\ \mathrm{km} & \text { kilometer(s) } \\ \mathrm{L} & \text { liter(s) }\end{array}$

$\begin{array}{ll}\mathrm{m} & \text { meter(s) } \\ \mathrm{m}^{2} & \text { square meter(s) } \\ \mathrm{m}^{3} & \text { cubic meter(s) } \\ \mathrm{mg} & \text { milligram(s) } \\ \mathrm{mi} & \text { mile(s) } \\ \mathrm{mph} & \text { mile(s) per hour } \\ \mathrm{mrem} & \text { millirem } \\ \mathrm{pCi} & \text { picocurie(s) } \\ \mathrm{s} & \text { second(s) } \\ \mathrm{yd}^{3} & \text { cubic yard(s) } \\ \mathrm{yr} & \text { year(s) }\end{array}$




\section{DERIVATION OF GUIDELINES FOR URANIUM RESIDUAL RADIOACTIVE MATERIAL IN SOIL AT THE NEW BRUNSWICK SITE, MIDDLESEX COUNTY, NEW JERSEY}

by

D. Dunning, S. Kamboj, M. Nimmagadda, and C. Yu

\section{SUMMARY}

Residual radioactive material guidelines for uranium in soil were derived for the New Brunswick Site, located in Middlesex County, New Jersey. This site has been designated for remedial action under the Formerly Utilized Sites Remedial Action Program of the U.S. Department of Energy (DOE). The site became contaminated as a result of operations conducted in support of the U.S. Atomic Energy Commission and its successor agencies between 1948 and 1977; activities conducted at the site included analytical and standards assay work related to nuclear and nonnuclear materials used for the reactor and weapons programs. Residual radioactive material guidelines for individual radionuclides of concern and total uranium were derived on the basis of the requirement that the 50-year committed effective dose equivalent to a hypothetical individual who lives or works in the immediate vicinity of the New Brunswick Site should not exceed a dose of $30 \mathrm{mrem} / \mathrm{yr}$ following remedial action for the current-use and likely future-use scenarios or a dose of $100 \mathrm{mrem} / \mathrm{yr}$ for less likely future-use scenarios. ${ }^{1}$ The DOE residual radioactive material guideline computer code, RESRAD, was used in this evaluation; RESRAD implements the methodology described in the DOE manual for establishing residual radioactive material guidelines.

Following shutdown of the New Brunswick facility in 1977, the process of decommissioning and preliminary decontamination was initiated in 1978 on the basis of a cleanup guideline of $15 \mathrm{pCi} / \mathrm{g}$ for americium-241. A second phase of remedial action conducted in 1983 included the removal of all buildings and sewer lines for off-site disposal. Cleanup guidelines established for this second phase of remediation included $200 \mathrm{pCi} / \mathrm{g}$ for total uranium, plutonium-239, and americium-241;25 pCi/g for natural thorium; and $5 \mathrm{pCi} / \mathrm{g}$ for radium-226. ${ }^{2}$

Remaining contamination at the site is thought to be limited to approximately $3,440 \mathrm{~m}^{3}$ of radioactively contaminated soil in the area of an inactive railroad spur in the eastern portion of the

1 Yu, C., et al., 1993, Manual for Implementing Residual Radioactive Material Guidelines Using RESRAD, Version 5.0: Working Draft for Comment, ANL/EAD/LD-2, Argonne National Laboratory, Argonne, Ill., Sept.

2 Argonne National Laboratory, 1984, Phase II Decontamination and Decommissioning of the New Brunswick Laboratory, ANL-OHS/HP-84-110, Argonne, Ill., Nov. 
site. ${ }^{3}$ The guidelines derived in this report are intended to apply to the remediation of these remaining residual radioactive materials at the site. The primary radionuclides of concern in these remaining materials are expected to be radium-226 and, to a lesser extent, natural uranium and thorium. The DOE has established generic cleanup guidelines for radium and thorium in soil; ${ }^{4}$ however, cleanup guidelines for other radionuclides must be derived on a site-specific basis. Site characterization data have not identified elevated concentrations of plutonium, americium, or cesium remaining at the site; however, if these radionuclides are encountered at levels of potential concern, separate guidelines will be developed.

Three potential scenarios were considered for the site. These scenarios vary with regard to future land use at the site, sources of water used, and sources of food consumed. The results of the evaluation indicate that the dose constraints would not be exceeded within 1,000 years, provided that the soil concentration of total uranium (including uranium-234, uranium-235, and uranium-238) at the site does not exceed $610 \mathrm{pCi} / \mathrm{g}$ for Scenario A (industrial worker - the current and expected future use of the site), $590 \mathrm{pCi} / \mathrm{g}$ for Scenario B (urban resident using a municipal water supply - a plausible but unlikely future use), and $430 \mathrm{pCi} / \mathrm{g}$ for Scenario C (resident using water from an on-site well for all purposes - a plausible but very unlikely future use).

The uranium guidelines derived in this analysis apply to the total activity concentration of uranium isotopes (i.e., uranium-238, uranium-234, and uranium-235) present in their natural activity concentration ratio of 1:1:0.046. Consequently, if uranium-238 is measured as the indicator radionuclide, the soil concentration limits would be $300 \mathrm{pCi} / \mathrm{g}$ for Scenario A, $290 \mathrm{pCi} / \mathrm{g}$ for Scenario B, and $210 \mathrm{pCi} / \mathrm{g}$ for Scenario C. These guidelines were calculated on the basis of a dose constraint of $30 \mathrm{mrem} / \mathrm{yr}$ for Scenario A and a dose limit of $100 \mathrm{mrem} / \mathrm{yr}$ for Scenarios B and C. ${ }^{1}$ In setting the actual residual radioactive material guidelines for this site, DOE will apply the "as low as reasonably achievable" (ALARA) policy to the decision-making process, along with other factors, such as whether a particular scenario is reasonable and appropriate and whether the contamination is isolated and localized.

3 Bechtel National, Inc., 1995, Remedial Action Plan for the New Brunswick Site, New Brunswick, New Jersey, DOE/OR/21949-380, Oak Ridge, Tenn., Jan.

4 U.S. Department of Energy, 1990, "Radiation Protection of the Public and the Environment," DOE Order 5400.5, Washington, D.C., Feb. 8. 


\section{INTRODUCTION}

The New Brunswick Site (NBS) is located in Middlesex County, New Jersey (Figure 1). This site was acquired by the U.S. Atomic Energy Commission (AEC) in 1948 and subsequently was used for assay of nuclear materials, spectrochemical analysis, and research and development. The NBS is currently owned by the U.S. Department of Energy (DOE) and has been designated by DOE for remedial action under its Formerly Utilized Sites Remedial Action Program (FUSRAP). FUSRAP was established in 1974 by the AEC, a predecessor agency of DOE, to identify, evaluate, and, if necessary, decontaminate sites previously used by the AEC or its predecessor, the Manhattan Engineer District, or otherwise designated for FUSRAP responsibility.

Remedial actions at the NBS will follow the guidelines established in DOE Order 5400.5 (DOE 1990). The DOE residual radioactive material guideline computer code, RESRAD (Yu et al. 1993a), is used to derive residual radionuclide guidelines on a site-specific basis. This report presents guidelines for residual concentrations of uranium in soils at the NBS, derived on the basis of a dose constraint of $30 \mathrm{mrem} / \mathrm{yr}$ for the current-use and likely future-use scenarios and a dose limit of $100 \mathrm{mrem} / \mathrm{yr}$ for less likely but plausible future-use scenarios (Yu et al. 1993a). The dose constraint of $30 \mathrm{mrem} / \mathrm{yr}$ is not currently required under DOE Order 5400.5 but is specified in the proposed rulemaking in Title 10, Code of Federal Regulations, Part 834 (10 CFR Part 834) (DOE 1993) to account for additional dose contributions from other potential sources of radiation exposure.

\subsection{SITE DESCRIPTION AND SETTING}

The NBS occupies $2.3 \mathrm{ha}$ ( 5.6 acres) in Middlesex County. The site is approximately $48 \mathrm{~km}$ $(30 \mathrm{mi})$ southwest of New York City, $95 \mathrm{~km}(60 \mathrm{mi})$ northeast of Philadelphia, and approximately $3.2 \mathrm{~km}(2 \mathrm{mi})$ southwest of downtown New Brunswick, New Jersey. All buildings at the NBS were removed prior to completion of previous remedial actions in 1983 (Figure 2). The site now consists of three of the original building pads and a parking area (Figure 3). The vacant grass-covered site is fenced to restrict public access.

Land use in the vicinity of the NBS is predominantly commercial and residential, with some forest and meadowland. The property is bordered by Jersey Avenue (Highway 91) to the north, active Amtrak rail lines and vacant property to the south, and commercial property to the east and west. No residential housing occurs within a $0.4-\mathrm{km}(0.25-\mathrm{mi})$ radius of the site. The residential population within $1.6 \mathrm{~km}(1 \mathrm{mi})$ of the site boundary is estimated at 30,000 . The total population of the area within an $80-\mathrm{km}(50-\mathrm{mi})$ radius of the NBS is approximately 15 million.

The regional climate is humid, with a mean annual precipitation of $1.1 \mathrm{~m}$ (42.0 in.). The annual daily maximum temperature for the area is $17^{\circ} \mathrm{C}\left(63^{\circ} \mathrm{F}\right)$, and the average daily minimum is $7^{\circ} \mathrm{C}\left(45^{\circ} \mathrm{F}\right)$. Winds are predominantly from the west at a mean speed of 14 to $18 \mathrm{~km} / \mathrm{h}$ (9 to $\left.11 \mathrm{mph}\right)$. 


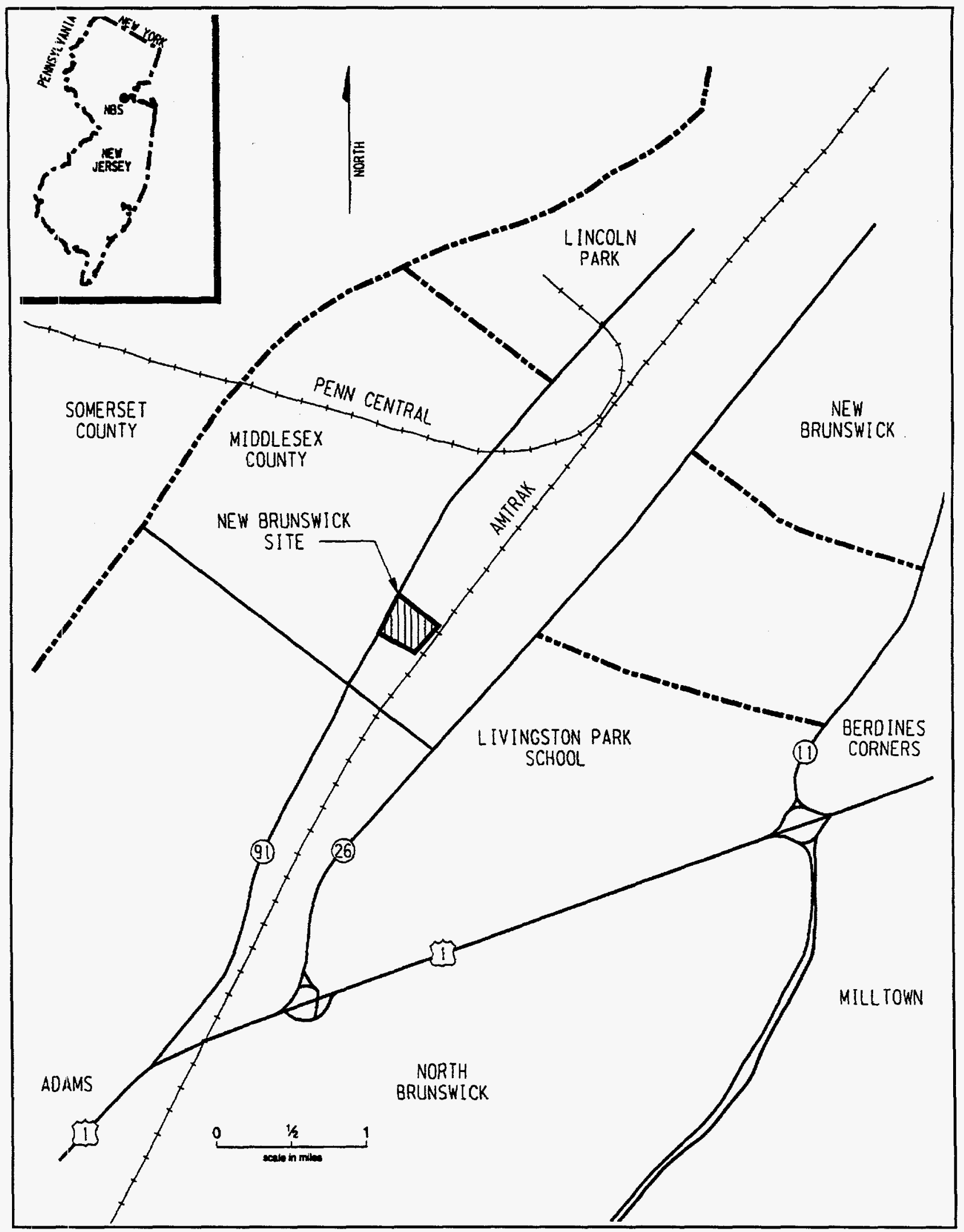

FIGURE 1 Location of the NBS (Source: BNI 1995) 


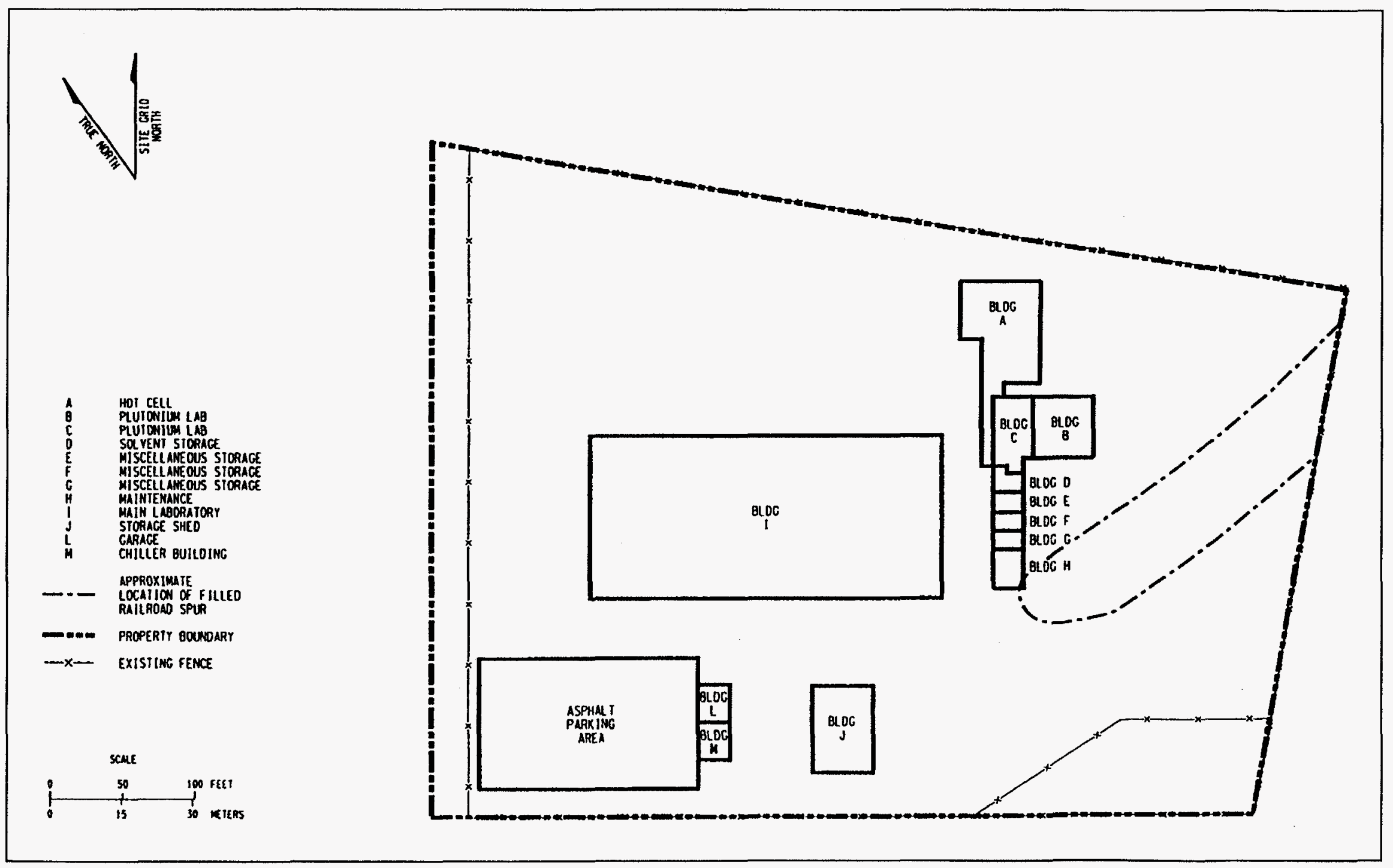

FIGURE 2 Plan View of the NBS before Decommissioning and Decontamination (Source: BNI 1995) 


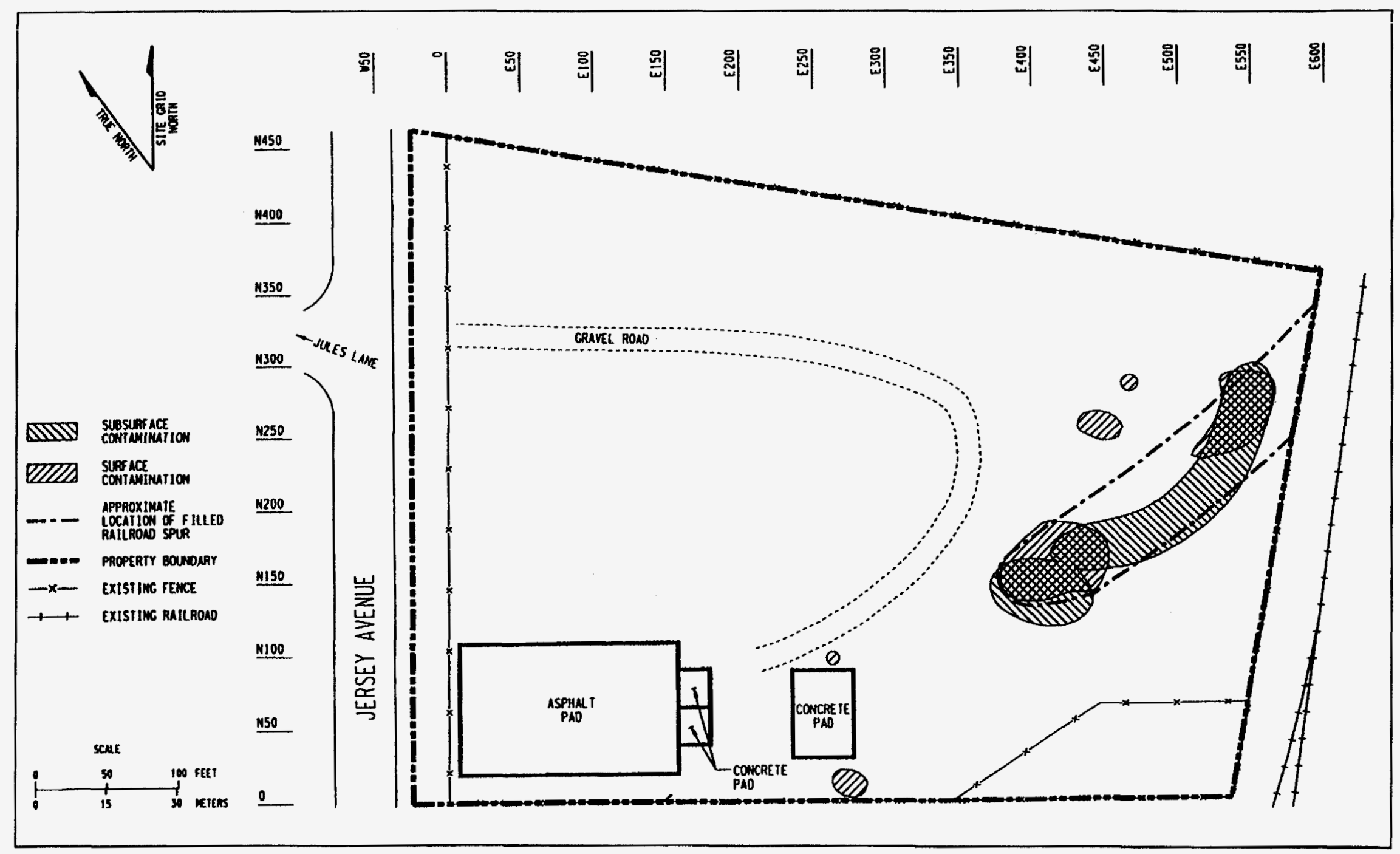

FIGURE 3 Plan View of the Current NBS (Source: BNI 1995) 


\subsection{SITE HISTORY}

Before 1948, the NBS was used by a manufacturing company under contract to the U.S. Navy to build pumps. In 1948, the AEC acquired the property, modified existing structures, and added new ones. The site consisted of the main building, a plutonium laboratory complex, a hot cell, and nine support structures (Figure 2). This facility was designated as the New Brunswick Laboratory.

In 1949, the AEC renovated and equipped the main building as a general nuclear chemistry laboratory for performing standards assays of nuclear and other materials used in AEC reactor and weapons programs. Several other projects grew out of this original assay work. The laboratory conducted spectrochemical analyses of lithium, magnesium, beryllium, zirconium, and other materials used in operating nuclear reactors. Numerous pilot projects were also conducted at the facility to develop methods for thorium extraction, production of green salt (uranium tetrafluoride), and recycling of boron products.

During its 29 years of operation, the New Brunswick Laboratory provided a variety of services that used nuclear materials such as thorium and uranium ores, high-purity plutonium, americium, and enriched uranium. Incidents of contamination occurred, and liquid waste containing various radionuclides was discharged into the sanitary sewer system, as permitted by the AEC criteria in effect at that time.

In 1960 , approximately $510 \mathrm{~m}^{3}\left(670 \mathrm{yd}^{3}\right)$ of soil contaminated with Belgian Congo pitchblende ore was transferred to the NBS from the Middlesex Municipal Landfill to reduce exposure levels at the landfill. The contaminated soil was mixed with clean soil, resulting in a total volume of $3,100 \mathrm{~m}^{3}\left(4,100 \mathrm{yd}^{3}\right)$ that was used as fill for an unused railroad spur (Argonne National Laboratory [ANL] 1984; Bechtel National, Inc. [BNI] 1995).

The assay work and associated activities continued until 1977, when the laboratory transferred its activities to ANL. Phase I remedial action (decommissioning and preliminary decontamination) was initiated at the site in 1978 under the direction of the DOE Surplus Facilities Management Program. During Phase II remedial action conducted in 1983, the structures and sewer lines were removed, and contaminated materials were transported off-site for disposal. Approximately $340 \mathrm{~m}^{3}\left(440 \mathrm{yd}^{3}\right)$ of radioactively contaminated soil from the site was placed near the pitchblende-contaminated soil on the railroad spur. A cleanup guideline of $15 \mathrm{pCi} / \mathrm{g}$ for americium-241 was used in Phase I. Guidelines for Phase II included $200 \mathrm{pCi} / \mathrm{g}$ for total uranium, plutonium-239, and americium-241;25 pCi/g for natural thorium; and $5 \mathrm{pCi} / \mathrm{g}$ for radium-226 (ANL 1982, 1984).

Remaining contamination at the site is thought to be limited to approximately $3,440 \mathrm{~m}^{3}$ of radioactively contaminated soil in the area of the inactive railroad spur in the eastern portion of the 
site (i.e., approximately $3,100 \mathrm{~m}^{3}$ of pitchblende-contaminated soils from the 1960 placement plus $340 \mathrm{~m}^{3}$ from the Phase II remediation). The guidelines derived in this report are intended to apply to the remediation of these remaining residual radioactive materials at the site. The primary radionuclides of concern in these remaining materials are expected to be radium-226 and, to a lesser extent, natural uranium and thorium.

Work since 1983 has included environmental monitoring, radiological surveys, and chemical and radiological sampling of the southeastern portion of the site, which contains the contaminated soils on the railroad spur. In 1990, responsibility for the site was transferred from the Surplus Facilities Management Program to FUSRAP.

\subsection{DERIVATION OF CLEANUP GUIDELINES}

On the basis of the site history, as discussed in Section 1.2, potential radioactive contaminants at the NBS include radium, thorium, uranium, plutonium, americium, and cesium; however, site characterization data indicate that contamination with cesium, plutonium, and americium was adequately removed during the previous remediation activities at the site and that the primary radionuclides of concern in the remaining contaminated soils are expected to be radium-226 and, to a lesser degree, uranium and thorium. The DOE has established generic cleanup guidelines for radium and thorium in soil (DOE 1990); however, cleanup guidelines for other radionuclides must be derived on a site-specific basis.

The purpose of this report is to present the derivation of the residual radioactive material guidelines for uranium (uranium-234, uranium-235, uranium-238, and total uranium) that are applicable to remedial action at the NBS. The derived guidelines represent the residual concentration of each radionuclide in a homogeneously contaminated area that must not be exceeded if the site is to be released for use without radiological restrictions. Guidelines for total uranium are derived by assuming that uranium-238, uranium-234, and uranium-235 are present in their natural activity concentration ratio of 1:1:0.046. While historical operations at the NBS also included management of enriched uranium ( $\leq 5 \%$ enrichment in uranium-235), this material was addressed in previous remediation activities; the residual radioactive materials remaining at the site consist primarily of soils contaminated with pitchblende ores, in which the uranium isotopes would be present at the natural activity concentration ratio.

The derivation of site-specific residual radioactive material guidelines for the NBS was based on a dose constraint of $30 \mathrm{mrem} / \mathrm{yr}$ for the current-use and likely future-use scenarios and a dose limit of $100 \mathrm{mrem} / \mathrm{yr}$ for less likely but plausible future-use scenarios (Yu et al. 1993a). For each radionuclide of concern, the assumption was that only that radionuclide was present at an above-background concentration. The RESRAD computer code, version 5.61, was used to derive these guidelines. The RESRAD code is used to implement the methodology described in the DOE 
manual for establishing residual radioactive material guidelines (Yu et al. 1993a). The DOE will establish the final guidelines for residual radioactive materials at this site by applying the "as low as reasonably achievable" (ALARA) policy to the derived guidelines presented in this report, along with other factors, such as whether a particular scenario is reasonable and appropriate and whether the contamination is isolated and localized. 


\section{SCENARIO DEFINITIONS}

Three potential exposure scenarios were considered for the NBS. In all scenarios, the assumption is that, at some time within 1,000 years, the site will be released for use without radiological restrictions following remediation.

Scenario A (the expected scenario) assumes continued industrial use of the site. A hypothetical employee is assumed to work in the decontaminated area for 8 hours per day ( 7 hours indoors and 1 hour outdoors), 5 days per week, 50 weeks per year. The industrial worker does not ingest drinking water, plant foods, or fish from the decontaminated area or ingest meat or milk from livestock raised in the decontaminated area.

Scenario B (a plausible but unlikely scenario) assumes residential use of the site. The resident is assumed to spend 12 hours per day indoors and 6 hours per day outdoors in the decontaminated area each day. The hypothetical resident is assumed to obtain all water from a distant source not affected by site conditions (e.g., the current municipal water supply). The resident ingests plant foods grown in a garden in the decontaminated area but does not ingest meat or milk from livestock raised in the decontaminated area or fish grown in a pond in the decontaminated area.

Scenario C (a plausible but very unlikely scenario) also assumes the presence of a resident at the site; however, the resident drinks water obtained from a well located at the downgradient edge of the decontaminated area, ingests plant foods grown in a garden in the decontaminated area, ingests fish taken from a pond that is assumed to be constructed adjacent to and downgradient of the decontaminated area, and ingests meat and milk from livestock raised in the decontaminated area. Assumptions regarding site occupancy are the same as for Scenario B. All water used for drinking, household purposes, irrigation, and livestock watering is assumed to be drawn from the on-site well. (No current agricultural activity exists at the site, and production of livestock or construction of a fishing pond in the decontaminated area is considered extremely unlikely.)

Potential radiation doses resulting from nine exposure pathways were analyzed: (1) direct exposure to external radiation from the decontaminated soil material, (2) internal radiation from inhalation of contaminated dust, (3) internal radiation from inhalation of emanating radon-222, (4) internal radiation from incidental ingestion of soil, (5) internal radiation from ingestion of plant foods grown in the decontaminated area and irrigated with water drawn from a well located at the downgradient edge of the decontaminated area, (6) internal radiation from ingestion of meat from livestock fed with fodder that is grown in the decontaminated area and irrigated with water drawn from the on-site well, (7) internal radiation from ingestion of milk from livestock fed with fodder that is grown in the decontaminated area and irrigated with water drawn from the on-site well, (8) internal radiation from ingestion of fish from a pond downgradient from the decontaminated area, and (9) internal radiation from drinking water drawn from the on-site well. 
The RESRAD computer code, version 5.61 (Yu et al. 1993a), was used to calculate the potential radiation doses to each of the hypothetical future receptors on the basis of the following assumptions:

- The industrial worker spends 2,000 hours per year on-site (7 hours per day indoors and 1 hour per day outdoors for 250 days per year). The resident spends 6,570 hours per year on-site in the decontaminated area (12 hours per day indoors and 6 hours per day outdoors for 365 days per year).

- The walls, floor, and foundation of the house or commercial building reduce external exposure by $30 \%$, and the indoor dust level is $40 \%$ of the outdoor dust level (Yu et al. 1993b).

- The outdoor airborne dust loading is assumed to be $0.1 \mathrm{mg} / \mathrm{m}^{3}$.

- The depth of the house or building foundation is set to maximize the radon inhalation dose but not to exceed $1 \mathrm{~m}$ below ground surface (RESRAD default is -1 ), with an effective radon diffusion coefficient of $3 \times 10^{-7} \mathrm{~m}^{2} / \mathrm{s}$ (Yu et al. 1993b).

- The size of the decontaminated area is large enough that $10 \%$ and $45 \%$ of the produce consumed by the resident in Scenario B and in Scenario C, respectively, are grown in a garden in the decontaminated area. The industrial worker does not consume produce from an on-site garden.

- Ingestion of meat or milk from livestock raised in the decontaminated area is considered for the resident in Scenario C only. The size of the decontaminated area produces $4.5 \%$ of the forage used to feed livestock used for meat and milk consumed by the resident in Scenario C.

- The site is currently served by an uncontaminated municipal water supply (Scenarios A and B); however, under Scenario C, a well located at the downgradient edge of the decontaminated area is assumed to provide all water for drinking, household purposes, livestock watering, and irrigation of the on-site garden.

- An on-site pond is assumed to provide $50 \%$ of the aquatic food (fish) consumed by the resident for Scenario C. The industrial worker (Scenario A) and the resident using a municipal water supply (Scenario B) do not consume any aquatic food from the decontaminated area. 
- After remedial action, no cover material is placed over the decontaminated area.

- No erosion of the contaminated material occurs.

- The contaminated area of $900 \mathrm{~m}^{2}$ of the site is conservatively assumed to be uniformly contaminated with residual radioactive materials to an average depth of $3.8 \mathrm{~m}$; this depth is derived by dividing the estimated volume of contaminated soil $\left(3,440 \mathrm{~m}^{3}\right)$ by the contaminated area of $900 \mathrm{~m}^{2}$ (according to the site characterization data [BNI 1995]) in the vicinity of the inactive rail spur in the eastern portion of the site.

- The distribution coefficient for uranium in soil was measured at $1,500 \mathrm{~cm}^{3} / \mathrm{g}$ (Orlandini 1995); this value is used for all uranium isotopes in the contaminated, unsaturated, and saturated zones. For all radioactive decay products, distribution coefficient values for clay soils are assumed (Yu et al. 1993b) because soils at the site are characterized as sandy, silty clays with a high organic content (ANL 1984). The measured value for uranium is very comparable to the typical value for clay soils of $1,600 \mathrm{~cm}^{3} / \mathrm{g}$.

- Site-specific estimates of hydrogeologic properties for the NBS are used for the following parameters: saturated/unsaturated zone total porosity, saturated/unsaturated zone effective porosity, saturated/unsaturated zone hydraulic conductivity, saturated zone hydraulic gradient, and unsaturated zone thickness (Skinner 1995). Site-specific meteorologic parameters include precipitation and wind speed (BNI 1995). In the absence of site-specific data for other parameters, other site characteristics are assumed to be adequately characterized by RESRAD default parameter values.

All pathways considered for Scenarios A, B, and C are summarized in Table 1. 
TABLE 1 Summary of Pathways Considered for Scenarios A, B, and C at the NBS $^{\mathrm{a}}$

\begin{tabular}{lccc}
\hline \multicolumn{1}{c}{ Pathway } & Scenario A & Scenario B & Scenario C \\
\hline & & & \\
External exposure & Yes & Yes & Yes \\
Particulate inhalation & Yes & Yes & Yes \\
Radon inhalation & Yes & Yes & Yes \\
Ingestion of soil & Yes & Yes & Yes \\
Ingestion of produce from on-site garden & No & Yes & Yes \\
Ingestion of meat from on-site livestock & No & No & Yes \\
Ingestion of milk from on-site livestock & No & No & Yes \\
Ingestion of fish from on-site pond & No & No & Yes \\
Ingestion of water from on-site well & No & No & Yes \\
\hline
\end{tabular}

a Scenario A, industrial worker; Scenario B, resident using a distant water source unaffected by site conditions; and Scenario C, resident using an on-site well as the only water source. 


\section{DOSE/SOURCE CONCENTRATION RATIOS}

The RESRAD computer code, version 5.61 (Yu et al. 1993a), was used to calculate the dose/source concentration ratio $D S R_{i p}(t)$ for radionuclide $I$ and pathway $p$ at time $t$ after remediation. The time frame considered in this analysis was 1,000 years. Radioactive decay and ingrowth were considered in deriving the dose/source concentration ratios. The various parameters used in the RESRAD code for this analysis are listed in the Appendix. The calculated maximum dose/source concentration ratios for all pathways are presented in Tables 2 through 4 for Scenarios A through C. For Scenarios $\mathrm{A}$ and $\mathrm{B}$, the maximum dose/source concentration ratios are predicted to occur at 1,000 years following remediation for uranium-234 and uranium-235 and at time zero (immediately after remediation) for uranium-238. For Scenario $\mathrm{C}$, the maximum dose/source concentration ratios are predicted to occur at 1,000 years for all radionuclides. The primary pathways for Scenarios $\mathrm{A}$ and $\mathrm{B}$ are inhalation and external exposure; for Scenario $\mathrm{C}$, ingestion pathways also contribute significantly.

The summation of $D S R_{i p}(t)$ for all pathways $p$ is the $D S R_{i}(t)$ for the $i$ th isotope, that is,

$$
\operatorname{DSR}_{i}(t)=\Sigma_{p} \operatorname{DSR}_{i p}(t)
$$

The total dose/source concentration ratio for total uranium can be calculated as

$$
\operatorname{DSR}(t)=\Sigma_{i} W_{i} \operatorname{DSR}_{i}(t)
$$

where $W_{i}$ is the existing activity concentration fraction in soil at the site for uranium-234, uranium-235, and uranium-238.

For this analysis, guideline values have been derived for total uranium, where $W_{i}$ is assumed to represent the natural activity concentration ratios of $1 / 2.046,1 / 2.046$, and $0.046 / 2.046$ for uranium-238, uranium-234, and uranium-235, respectively. The total dose/source concentration ratios for single radionuclides and total uranium are provided in Table 5. These ratios were used to determine the allowable residual radioactivity for uranium at the NBS.

Uncertainty in the derivation of dose/source concentration ratios arises from the distribution of possible input parameter values, as well as uncertainty in the conceptual model used to represent the site. Depending on the scenario, different parameters influence the results in each case. For all scenarios considered, the external exposure and particulate inhalation pathways are important contributors to dose. Therefore, uncertainties in parameters affecting these pathways (e.g., occupancy factors, thickness of the contaminated zone, shielding provided by buildings and site 
TABLE 2 Maximum Dose/Source Concentration Ratios for Scenario A (Industrial Worker) at the NBS

\begin{tabular}{|c|c|c|c|}
\hline \multirow[b]{2}{*}{ Pathway } & \multicolumn{3}{|c|}{$\begin{array}{l}\text { Maximum Dose/Source Concentration Ratio } \\
(\mathrm{mrem} / \mathrm{yr}) /(\mathrm{pCi} / \mathrm{g})\end{array}$} \\
\hline & Uranium-234 & Uranium-235 & Uranium-238 \\
\hline External exposure & $2.9 \times 10^{-3}$ & $1.2 \times 10^{-1}$ & $2.1 \times 10^{-2}$ \\
\hline Particulate inhalation & $1.1 \times 10^{-2}$ & $2.3 \times 10^{-2}$ & $9.9 \times 10^{-3}$ \\
\hline Radon inhalation & $4.5 \times 10^{-2}$ & 0 & 0 \\
\hline Ingestion of soil & $2.1 \times 10^{-3}$ & $5.7 \times 10^{-3}$ & $2.0 \times 10^{-3}$ \\
\hline
\end{tabular}

a Maximum dose/source concentration ratios are predicted to occur at time zero (immediately following remedial action) for uranium-238 and at 1,000 years following the remedial action for uranium-234 and uranium-235; all values are reported to two significant figures.

TABLE 3 Maximum Dose/Source Concentration Ratios for Scenario B (Resident Using Municipal Water Supply) at the NBS

\begin{tabular}{lccc}
\hline & \multicolumn{3}{c}{$\begin{array}{c}\text { Maximum Dose/Source Concentration Ratio } \\
\text { Pathway }\end{array}$} \\
\cline { 2 - 4 } \multicolumn{1}{c}{ Patyr)/(pCi/g) } & \\
\cline { 2 - 4 } & Uranium-234 & Uranium-235 & Uranium-238 \\
\hline External exposure & $1.0 \times 10^{-2}$ & $4.1 \times 10^{-1}$ & $7.4 \times 10^{-2}$ \\
Particulate inhalation & $4.3 \times 10^{-2}$ & $9.3 \times 10^{-2}$ & $4.1 \times 10^{-2}$ \\
Radon inhalation & $1.1 \times 10^{-1}$ & 0 & 0 \\
Ingestion of soil & $7.0 \times 10^{-3}$ & $1.8 \times 10^{-2}$ & $6.6 \times 10^{-3}$ \\
Ingestion of produce from on-site garden & $1.5 \times 10^{-2}$ & $6.0 \times 10^{-2}$ & $1.2 \times 10^{-2}$ \\
\hline
\end{tabular}

a Maximum dose/source concentration ratios are predicted to occur at time zero (immediately following remedial action) for uranium-238 and at 1,000 years following the remedial action for uranium-234 and uranium-235; all values are reported to two significant figures. 
TABLE 4 Maximum Dose/Source Concentration Ratios for Scenario C (Resident Using On-Site Well) at the NBS

\begin{tabular}{|c|c|c|c|}
\hline \multirow[b]{2}{*}{ Pathway } & \multicolumn{3}{|c|}{$\begin{array}{l}\text { Maximum Dose/Source Concentration Ratio } \\
(\mathrm{mrem} / \mathrm{yr}) /(\mathrm{pCi} / \mathrm{g})\end{array}$} \\
\hline & Uranium-234 & Uranium-235 & Uranium-238 \\
\hline External exposure & $1.0 \times 10^{-2}$ & $4.1 \times 10^{-1}$ & $6.9 \times 10^{-2}$ \\
\hline Particulate inhalation & $4.3 \times 10^{-2}$ & $9.3 \times 10^{-2}$ & $3.8 \times 10^{-2}$ \\
\hline Radon inhalation & $1.1 \times 10^{-1}$ & 0 & $1.1 \times 10^{-4}$ \\
\hline Ingestion of soil & $7.0 \times 10^{-3}$ & $1.8 \times 10^{-2}$ & $6.2 \times 10^{-3}$ \\
\hline Ingestion of produce from on-site garden & $6.9 \times 10^{-2}$ & $2.7 \times 10^{-1}$ & $5.1 \times 10^{-2}$ \\
\hline Ingestion of meat from on-site livestock & $2.3 \times 10^{-4}$ & $3.7 \times 10^{-3}$ & $1.7 \times 10^{-4}$ \\
\hline Ingestion of milk from on-site livestock & $4.8 \times 10^{-4}$ & $4.3 \times 10^{-4}$ & $4.2 \times 10^{-4}$ \\
\hline Ingestion of fish from on-site pond & $5.3 \times 10^{-6}$ & $2.0 \times 10^{-5}$ & $3.8 \times 10^{-6}$ \\
\hline Ingestion of water from on-site well & $1.3 \times 10^{-2}$ & $2.1 \times 10^{-2}$ & $1.3 \times 10^{-2}$ \\
\hline
\end{tabular}

a Maximum dose/source concentration ratios are predicted to occur at 1,000 years following the remedial action; all values are reported to two significant figures.

TABLE 5 Total Dose/Source Concentration Ratios for the NBS

\begin{tabular}{lccc}
\hline & \multicolumn{3}{c}{ Total Dose/Source Concentration Ratio $^{\mathrm{a}}$} \\
& \multicolumn{3}{c}{${ }^{(\mathrm{mrem} / \mathrm{yr}) /(\mathrm{pCi} / \mathrm{g})}$} \\
\cline { 2 - 4 } Radionuclide & Scenario A $^{\mathrm{b}}$ & Scenario B $^{\mathrm{c}}$ & Scenario C $^{\mathrm{d}}$ \\
\hline Uranium-234 & $6.1 \times 10^{-2}$ & $1.9 \times 10^{-1}$ & $2.6 \times 10^{-1}$ \\
Uranium-235 & $1.5 \times 10^{-1}$ & $5.8 \times 10^{-1}$ & $8.2 \times 10^{-1}$ \\
Uranium-238 & $3.3 \times 10^{-2}$ & $1.3 \times 10^{-1}$ & $1.8 \times 10^{-1}$ \\
Total uranium & $4.9 \times 10^{-2}$ & $1.7 \times 10^{-1}$ & $2.3 \times 10^{-1}$ \\
\hline
\end{tabular}

a All values are reported to two significant figures.

b Industrial worker (current-use scenario: 30 -mrem/yr dose constraint).

c Resident using water from uncontaminated municipal sources (plausible but unlikely future-use scenario: $100-\mathrm{mrem} / \mathrm{yr}$ dose limit).

d Resident using water from on-site well for drinking, household purposes, livestock watering, and irrigation (plausible but very unlikely future-use scenario: 100 -mrem/yr dose limit). 
features, mass loading of contaminated airborne particulates, and inhalation rate) have the greatest impact on the model predictions, and parameters related to other pathways have relatively little impact. For uranium-234 and uranium-235 under all scenarios and uranium-238 under Scenario C, the maximum dose occurs at 1,000 years following the remedial action; uncertainties in parameters related to the leaching and transport of radionuclides from the contaminated zone also affect the results in these cases (e.g., the uncertainties in soil properties, meteorologic parameters, distribution coefficients, and water consumption rates).

For the purposes of this analysis, RESRAD default parameter values were used if no sitespecific data were available. These default values are based on national average or reasonable maximum values. The area of the contaminated zone used in this analysis was $900 \mathrm{~m}^{2}$, equivalent to the estimated size of the contamination found during site surveys (BNI 1995). If the total area of the site, $23,000 \mathrm{~m}^{2}$, were used in the analysis, the dose/source concentration ratio would increase less than $6 \%$ for Scenarios A and B and less than $15 \%$ for Scenario C.

Furthermore, some of the exposure pathways evaluated in this analysis have been included for purposes of completeness but are considered very unlikely; for example, the production of meat and milk from livestock raised on-site and the development of a fishing pond are considered under Scenario $\mathrm{C}$ but are extremely unlikely, given the urban location and physical characteristics of the site. Therefore, the calculated dose/source concentration ratios are considered to be highly conservative (i.e., likely to overestimate doses). 


\section{RESIDUAL RADIOACTIVE MATERIAL GUIDELINES}

The residual radioactive material guideline is the concentration of residual radioactive material that can remain in a decontaminated area and still allow use of the area without radiological restrictions. Given a dose limit $D L$ for an individual, the residual radioactive material guideline $G$ for each radionuclide of concern at the NBS can be calculated as

$$
G=D L / D S R
$$

where $D S R$ is the total dose/source concentration ratio listed in Table 5. The dose limit $D L$ used to derive the residual radioactive material guidelines is $30 \mathrm{mrem} / \mathrm{yr}$ for the current-use and likely future-use scenarios and $100 \mathrm{mrem} / \mathrm{yr}$ for all other plausible future-use scenarios (DOE 1990; Yu et al. 1993a). The calculated residual radioactive material guidelines for individual radionuclides of interest (uranium-234, uranium-235, and uranium-238) and total uranium are presented in Table 6.

For the calculation of the total uranium guidelines, the assumption was that the activity concentration ratio of uranium-238, uranium-234, and uranium-235 is 1:1:0.046 (i.e., typical activity concentration ratio for natural uranium). The derived guidelines for total uranium for Scenarios A, $\mathrm{B}$, and $\mathrm{C}$ are $610 \mathrm{pCi} / \mathrm{g}, 590 \mathrm{pCi} / \mathrm{g}$, and $430 \mathrm{pCi} / \mathrm{g}$, respectively. If uranium- 238 is measured as the

TABLE 6 Residual Radioactive Material Guidelines for the NBS

\begin{tabular}{lccc}
\hline & \multicolumn{3}{c}{ Guideline $^{\mathrm{a}}(\mathrm{pCi} / \mathrm{g})$} \\
\cline { 2 - 4 } Radionuclide & Scenario $^{\mathrm{b}}$ & Scenario B $^{\mathrm{c}}$ & Scenario C $^{\mathrm{d}}$ \\
\hline & & & \\
Uranium-234 & 490 & 530 & 390 \\
Uranium-235 & 210 & 170 & 120 \\
Uranium-238 & 910 & 750 & 560 \\
Total uranium & 610 & 590 & 430 \\
\hline
\end{tabular}

a All values are reported to two significant figures.

b Industrial worker (current-use scenario: 30 -mrem/yr dose constraint).

c Resident using water from uncontaminated municipal sources (plausible but unlikely future-use scenario: 100-mrem/yr dose limit).

d Resident using water from on-site well for drinking, household purposes, livestock watering, and irrigation (plausible but very unlikely future-use scenario: $100-\mathrm{mrem} / \mathrm{yr}$ dose limit). 
indicator radionuclide, the uranium-238 limits for total uranium can be calculated by dividing the total uranium guidelines by 2.046 ; the resulting uranium- 238 limits would be $300 \mathrm{pCi} / \mathrm{g}, 290 \mathrm{pCi} / \mathrm{g}$, and $210 \mathrm{pCi} / \mathrm{g}$ for Scenarios A, B, and C, respectively. ${ }^{5}$

The sum-of-the-fractions rule applies when the derived radionuclide guidelines for remediation of a site are implemented. The summation of the radionuclide concentrations, $S_{i}$, remaining on-site following decontamination (averaged over an area of $100 \mathrm{~m}^{2}$ and a depth of $15 \mathrm{~cm}$ ) divided by their respective guidelines, $G_{i}$, should not be greater than unity:

$$
\Sigma_{i} S_{i} / G_{i} \leq 1
$$

The residual guidelines for uranium, as approved by DOE, will be implemented in conjunction with the authorized guidelines for radium and thorium by using the sum-of-the-fractions rule (DOE 1990).

The derived guidelines presented in Table 6 apply to a large homogeneously contaminated area. For a small isolated area of contamination (i.e., a hot spot), the allowable concentration that can remain on-site may be higher than the homogeneous guideline, depending on the size of the area of contamination and in accordance with the ranges given in Table 7.

\section{TABLE 7 Ranges for Hot-Spot Multiplication Factors}

\begin{tabular}{lc}
\hline \multicolumn{1}{c}{ Range } & $\begin{array}{c}\text { Factor (Multiple of } \\
\text { Authorized Limit) }\end{array}$ \\
\hline$<1 \mathrm{~m}^{2}$ & $10^{\mathrm{a}}$ \\
1 to $<3 \mathrm{~m}^{2}$ & 6 \\
3 to $<10 \mathrm{~m}^{2}$ & 3 \\
$10-25 \mathrm{~m}^{2}$ & 2 \\
\hline
\end{tabular}

a Areas less than $1 \mathrm{~m}^{2}$ are to be averaged over an area of $1 \mathrm{~m}^{2}$, and that average shall not exceed 10 times the authorized limit.

Source: Yu et al. (1993a).

5 Historical operations at the NBS also included management of slightly enriched uranium ( $\leq 5 \%$ enrichment in uranium-235); however, contamination with enriched uranium is thought to have been remediated during previous remedial activities at the site, and the residual radioactive materials remaining at the site consist primarily of soils contaminated with pitchblende ores, in which the uranium isotopes would be present at the natural activity concentration ratios. For this range of enrichment, the dose/source concentration ratios and soil guidelines for total uranium would not change significantly, and values for uranium-234 can be used as reasonable approximations for total uranium for enrichments up to $5 \%$. 


\section{REFERENCES}

ANL: See Argonne National Laboratory.

Argonne National Laboratory, 1982, Interim Radiological Site Characterization and D\&D Status Report, New Brunswick Laboratory, New Jersey Site, ANL-OHS/HP-81-101-Rev., April.

Argonne National Laboratory, 1984, Phase II Decontamination and Decommissioning of the New Brunswick Laboratory, ANL-OHS/HP-84-110, Argonne, Ill., Nov.

Bechtel National, Inc., 1995, Remedial Action Plan for the New Brunswick Site, New Brunswick, New Jersey, DOE/OR/21949-380, Oak Ridge, Tenn., Jan.

BNI: See Bechtel National, Inc.

DOE: See U.S. Department of Energy.

Orlandini, K., 1995, unpublished information.

Skinner, K.R., 1995, personal communication from Skinner (Bechtel National, Inc., Oak Ridge, Tenn.) to D.E. Dunning (Argonne National Laboratory, Oak Ridge, Tenn.), May 18.

U.S. Department of Energy, 1990, "Radiation Protection of the Public and the Environment," DOE Order 5400.5, Washington, D.C., Feb. 8.

U.S. Department of Energy, 1993, "Radiation Protection of the Public and the Environment," Notice of Proposed Rulemaking (10 CFR Part 834), Federal Register 58(56)16268, March 25.

Yu, C., et al., 1993a, Manual for Implementing Residual Radioactive Material Guidelines Using RESRAD, Version 5.0: Working Draft for Comment, ANL/EAD/LD-2, Argonne National Laboratory, Argonne, Ill., Sept.

Yu, C., et al., 1993b, Data Collection Handbook to Support Modeling the Impacts of Radioactive Material in Soil, ANL/EAIS-8, Argonne National Laboratory, Argonne, Ill., April. 


\section{APPENDIX:}

\section{SCENARIOS AND PARAMETERS USED FOR THE ANALYSIS OF THE NBS}

The following exposure scenarios were analyzed for the New Brunswick Site (NBS) in New Brunswick, Middlesex County, New Jersey:

- Scenario A: Industrial Use of the Site. A hypothetical person is assumed to work in the decontaminated area of the site.

- Scenario B: Residential Use of the Site: Municipal Water Supply. A hypothetical person is assumed to live in the decontaminated area and to use an uncontaminated water source (e.g., municipal water supply) for drinking, household purposes, and irrigation. The resident is assumed to ingest produce grown in an on-site garden; however, no livestock are raised for the production of meat or milk, and no pond is constructed on-site to provide fish and other aquatic foods.

- Scenario C: Residential Use of the Site: On-Site Well. A hypothetical person is assumed to live in the decontaminated area and to use water from an on-site well for drinking, household purposes, livestock watering, and irrigation. The resident is assumed to ingest plant foods grown on-site, meat and milk from livestock fed with forage grown in the decontaminated area, and fish from an on-site pond.

The parametric values used in the RESRAD code for the analysis of the NBS are listed in Table A.1. All parametric values are reported to two significant figures. Some parameters are specific to the site, while other values are generic. 
TABLE A.1 Parameters Used in the RESRAD Code for the Analysis of the NBS

\begin{tabular}{|c|c|c|c|c|}
\hline \multirow[b]{2}{*}{ Parameter $^{\mathrm{a}}$} & \multirow[b]{2}{*}{ Unit } & \multicolumn{3}{|c|}{ Value } \\
\hline & & Scenario A & Scenario B & Scenario $\mathrm{C}$ \\
\hline Dose limit & $\mathrm{mrem} / \mathrm{yr}$ & 30 & 100 & 100 \\
\hline Area of contaminated zone ${ }^{b}$ & $\mathrm{~m}^{2}$ & 900 & 900 & 900 \\
\hline Thickness of contaminated zone ${ }^{b}$ & $\mathrm{~m}$ & 3.8 & 3.8 & 3.8 \\
\hline Length parallel to aquifer flow ${ }^{b}$ & $\mathrm{~m}$ & 30 & 30 & 30 \\
\hline Cover depth & $\mathrm{m}$ & 0 & 0 & 0 \\
\hline Density of contaminated zone & $\mathrm{g} / \mathrm{cm}^{3}$ & 1.5 & 1.5 & 1.5 \\
\hline Contaminated zone erosion rate & $\mathrm{m} / \mathrm{yr}$ & 0 & 0 & 0 \\
\hline Contaminated zone total porosity ${ }^{c}$ & $-d$ & 0.30 & 0.30 & 0.30 \\
\hline Contaminated zone effective porosity ${ }^{c}$ & - & 0.03 & 0.03 & 0.03 \\
\hline Contaminated zone hydraulic conductivity ${ }^{c}$ & $\mathrm{~m} / \mathrm{yr}$ & 300 & 300 & 300 \\
\hline Contaminated zone "b" parameter & - & 7.1 & 7.1 & 7.1 \\
\hline Evapotranspiration coefficient & - & 0.5 & 0.5 & 0.5 \\
\hline Precipitation $^{c}$ & $\mathrm{~m} / \mathrm{yr}$ & 1.1 & 1.1 & 1.1 \\
\hline Irrigation & $\mathrm{m} / \mathrm{yr}$ & 0.2 & 0.2 & 0.2 \\
\hline Irrigation mode & - & Not used & Overhead & Overhead \\
\hline Rurioff coefficient & - & 0.2 & 0.2 & 0.2 \\
\hline Wafershed area for pond & $\mathrm{m}^{2}$ & Not used & Not used & $1,000,000$ \\
\hline Density of saturated zone & $\mathrm{g} / \mathrm{cm}^{3}$ & Not used & Not used & 1.5 \\
\hline Saturated zone total porosity ${ }^{\mathrm{c}}$ & - & Not used & Not used & 0.30 \\
\hline Saturated zone effective porosity ${ }^{\mathbf{c}}$ & - & Not used & Not used & 0.03 \\
\hline Saturated zone hydraulic conductivity ${ }^{\mathrm{c}}$ & $\mathrm{m} / \mathrm{yr}$ & Not used & Not used & 300 \\
\hline Saturated zone hydraulic gradient ${ }^{\mathfrak{c}}$ & - & Not used & Not used & 0.017 \\
\hline Saturated zone "b" parameter & - & Not used & Not used & 7.1 \\
\hline Water table drop rate & $\mathrm{m} / \mathrm{yr}$ & Not used & Not used & 0 \\
\hline $\begin{array}{l}\text { Well pump intake depth } \\
\text { (below water table) }\end{array}$ & $\mathrm{m}$ & Not used & Not used & 10 \\
\hline Well pumping rate & $\mathrm{m}^{3} / \mathrm{yr}$ & Not used & Not used & 250 \\
\hline $\begin{array}{l}\text { Model: nondispersion (ND) or } \\
\text { mass balance (MB) }\end{array}$ & - & Not used & Not used & ND \\
\hline Nurnber of unsaturated zone strata & - & Not used & Not used & 1 \\
\hline${\text { Unsaturated zone } 1 \text { thickness }^{c}}^{c}$ & $\mathrm{~m}$ & Not used & Not used & 1 \\
\hline Unsaturated zone 1 soil density & $\mathrm{g} / \mathrm{cm}^{3}$ & Not used & Not used & 1.5 \\
\hline Unsaturated zone 1 total porosity ${ }^{\mathfrak{c}}$ & - & Not used & Not used & 0.30 \\
\hline Unsaturated zone 1 effective porosity ${ }^{\mathcal{C}}$ & - & Not used & Not used & 0.03 \\
\hline Unsaturated zone 1 soil " $b$ " parameter & - & Not used & Not used & 7.1 \\
\hline Unsaturated zone 1 hydraulic conductivity $^{c}$ & $\mathrm{~m} / \mathrm{yr}$ & Not used & Not used & 300 \\
\hline \multicolumn{5}{|l|}{ Distribution coefficient (all zones) } \\
\hline Uranium-238 & $\mathrm{cm}^{3} / \mathrm{g}$ & 1,500 & 1,500 & 1,500 \\
\hline Uranium-235 $5^{e}$ & $\mathrm{~cm}^{3} / \mathrm{g}$ & 1,500 & 1,500 & 1,500 \\
\hline Uranium-234 ${ }^{\mathrm{e}}$ & $\mathrm{cm}^{3} / \mathrm{g}$ & 1,500 & 1,500 & 1,500 \\
\hline
\end{tabular}


TABLE A.1 (Cont.)

\begin{tabular}{|c|c|c|c|c|}
\hline \multirow[b]{2}{*}{ Parameter $^{\mathbf{a}}$} & \multirow[b]{2}{*}{ Unit } & \multicolumn{3}{|c|}{ Value } \\
\hline & & Scenario A & Scenario B & Scenario C \\
\hline \multicolumn{5}{|l|}{ Distribution coefficient (all zones) (cont.) } \\
\hline Protactinium-231 $\mathrm{e}, \mathrm{f}$ & $\mathrm{cm}^{3} / \mathrm{g}$ & 2,700 & 2,700 & 2,700 \\
\hline Thorium-230 $0^{\mathrm{e}, \mathrm{f}}$ & $\mathrm{cm}^{3} / \mathrm{g}$ & 5,800 & 5,800 & 5,800 \\
\hline Actinium-227 $7^{\mathrm{e}, \mathrm{f}}$ & $\mathrm{cm}^{3} / \mathrm{g}$ & 2,400 & 2,400 & 2,400 \\
\hline Radium-226 $6^{e, f}$ & $\mathrm{~cm}^{3} / \mathrm{g}$ & 9,100 & 9,100 & 9,100 \\
\hline Lead-210 ${ }^{\text {e,f }}$ & $\mathrm{cm}^{3} / \mathrm{g}$ & 550 & 550 & 550 \\
\hline Inhalation rate & $\mathrm{m}^{3 / \mathrm{yr}}$ & 8,400 & 8,400 & 8,400 \\
\hline Mass loading for inhalation & $\mathrm{g} / \mathrm{m}^{3}$ & 0.0001 & 0.0001 & 0.0001 \\
\hline Indoor occupancy time fraction & - & 0.2 & 0.50 & 0.50 \\
\hline Outdoor occupancy time fraction & - & 0.03 & 0.25 & 0.25 \\
\hline $\begin{array}{l}\text { Shielding factor from external radiation } \\
\text { afforded by indoor occupancy }\end{array}$ & - & 0.7 & 0.7 & 0.7 \\
\hline Fraction of outdoor dust present indoors & - & 0.4 & 0.4 & 0.4 \\
\hline Shape factor, external gamma & - & 1 & 1 & 1 \\
\hline Dilution length for airborne dust inhalation & $\mathrm{m}$ & 3 & 3 & 3 \\
\hline Soil ingestion rate & $\mathrm{g} / \mathrm{yr}$ & 36.5 & 36.5 & 36.5 \\
\hline Fruit, vegetable, and grain consumption & $\mathrm{kg} / \mathrm{yr}$ & Not used & 160 & 160 \\
\hline Leafy vegetable consumption & $\mathrm{kg} / \mathrm{yr}$ & Not used & 14 & 14 \\
\hline Milk consumption from on-site livestock & $\mathrm{L} / \mathrm{yr}$ & Not used & Not used & 92 \\
\hline Meat consumption from on-site livestock & $\mathrm{kg} / \mathrm{yr}$ & Not used & Not used & 63 \\
\hline Fish consumption & $\mathrm{kg} / \mathrm{yr}$ & Not used & Not used & 5.4 \\
\hline Other seafood consumption & $\mathrm{kg} / \mathrm{yr}$ & Not used & Not used & 0.9 \\
\hline Drinking water intake & $\mathrm{L} / \mathrm{yr}$ & Not used & Not used & 510 \\
\hline \multicolumn{5}{|l|}{ Storage time for: } \\
\hline Fruits, nonleafy vegetables, and grain & $\mathrm{d}$ & Not used & Not used & 14 \\
\hline Leafy vegetables & $\mathrm{d}$ & Not used & Not used & 1 \\
\hline Milk & $\mathrm{d}$ & Not used & Not used & 1 \\
\hline Meat & d & Not used & Not used & 20 \\
\hline Fish and seafood & $\mathrm{d}$ & Not used & Not used & 7 \\
\hline Drinking water (well or surface water) & d & Not used & Not used & 1 \\
\hline Livestock fodder & d & Not used & Not used & 45 \\
\hline Fraction of drinking water from on-site well & - & Not used & Not used & 1 \\
\hline Fraction of aquatic food from on-site pond & - & Not used & Not used & 0.5 \\
\hline Livestock fodder intake for meat & $\mathrm{kg} / \mathrm{d}$ & Not used & Not used & 68 \\
\hline Livestock fodder intake for milk & $\mathrm{kg} / \mathrm{d}$ & Not used & Not used & 55 \\
\hline Livestock water intake for meat & $\mathrm{L} / \mathrm{d}$ & Not used & Not used & 50 \\
\hline Livestock water intake for milk & $L / d$ & Not used & Not used & 160 \\
\hline Livestock intake of soil & $\mathrm{kg} / \mathrm{d}$ & Not used & Not used & 0.5 \\
\hline Mass loading for foliar deposition & $\mathrm{g} / \mathrm{m}^{3}$ & Not used & 0.0001 & 0.0001 \\
\hline Depth of soil mixing layer & $\mathrm{m}$ & Not used & 0.15 & 0.15 \\
\hline
\end{tabular}


TABLE A.1 (Cont.)

\begin{tabular}{|c|c|c|c|c|}
\hline \multirow[b]{2}{*}{ Parameter $^{a}$} & \multirow[b]{2}{*}{ Unit } & \multicolumn{3}{|c|}{ Value } \\
\hline & & Scenario A & Scenario B & Scenario C \\
\hline Depth of roots & $\mathrm{m}$ & Not used & 0.9 & 0.9 \\
\hline \multicolumn{5}{|l|}{ Contamination fraction } \\
\hline Drinking water & - & Not used & Not used & 1 \\
\hline Household water & - & Not used & 0 & 1 \\
\hline Livestock & - & Not used & Not used & 1 \\
\hline Irrigation & - & Not used & 0 & 1 \\
\hline Produce & - & Not used & 0.1 & $0.45^{\mathrm{g}}$ \\
\hline Meat & - & Not used & Not used & $0.045^{g}$ \\
\hline Milk & - & Not used & Not used & $0.045^{\mathrm{g}}$ \\
\hline \multicolumn{5}{|l|}{$\begin{array}{l}\text { Groundwater fractional usage } \\
\text { (balance from surface water) }\end{array}$} \\
\hline Drinking water & - & Not used & Not used & 1 \\
\hline Household water & - & Not used & Not used & 1 \\
\hline Livestock water & - & Not used & Not used & 1 \\
\hline Irrigation & - & Not used & Not used & 1 \\
\hline Total porosity of the house or building & - & 0.1 & 0.1 & 0.1 \\
\hline Volumetric water content of cover material & - & Not used & Not used & Not used \\
\hline Volumetric water content of the foundation & - & 0.03 & 0.03 & 0.03 \\
\hline $\begin{array}{l}\text { Diffusion coefficient for radon gas } \\
\text { In cover material }\end{array}$ & $\mathrm{m}^{2} / \mathrm{s}$ & Not used & Not used & Not used \\
\hline In foundation material & $\mathrm{m}^{2} / \mathrm{s}$ & $3.0 \times 10^{-7}$ & $3.0 \times 10^{-7}$ & $3.0 \times 10^{-7}$ \\
\hline In contaminated zone material & $\mathrm{m}^{2} / \mathrm{s}$ & $2.0 \times 10^{-6}$ & $2.0 \times 10^{-6}$ & $2.0 \times 10^{-6}$ \\
\hline Emanating power of radon gas & - & 0.25 & 0.25 & 0.25 \\
\hline Radon vertical dimension of mixing & $\mathrm{m}$ & 2.0 & 2.0 & 2.0 \\
\hline Average annual wind speed ${ }^{\mathfrak{c}}$ & $\mathrm{m} / \mathrm{s}$ & 4.5 & 4.5 & 4.5 \\
\hline Average building air exchange rate & $h^{-1}$ & 0.5 & 0.5 & 0.5 \\
\hline Height of the building (room) & $\mathrm{m}$ & 2.5 & 2.5 & 2.5 \\
\hline Bulk density of building foundation & $\mathrm{g} / \mathrm{cm}^{3}$ & 2.4 & 2.4 & 2.4 \\
\hline Thickness of building foundation & $\mathrm{m}$ & 0.15 & 0.15 & 0.15 \\
\hline Building indoor area factor & - & 0 & 0 & 0 \\
\hline Building depth below ground surface ${ }^{h}$ & $\mathrm{~m}$ & -1 & -1 & -1 \\
\hline
\end{tabular}

a Parameter values listed are generic (RESRAD default) values except where indicated differently (Yu et al. 1993a,b).

${ }^{b}$ For purposes of this analysis, the site is assumed to be uniformly contaminated over a $900-\mathrm{m}^{2}$ area to a depth of $3.8 \mathrm{~m}$.

c Site-specific estimate (BNI 1995; Skinner 1995).

d Parameter is dimensionless.

e Distribution coefficient values for uranium are based on laboratory analyses of site-specific soil samples (Orlandini 1995); for other radionuclides, values appropriate for clay soils are assumed.

f Radionuclide is a decay product.

g Calculated by RESRAD on the basis of the area of the contaminated zone.

${ }^{\mathrm{h}}$ Depth calculated by RESRAD in the range 0-1 $\mathrm{m}$ to maximize radon inhalation dose (RESRAD default). 


\section{APPENDIX REFERENCES}

Bechtel National, Inc., 1995, Remedial Action Plan for the New Brunswick Site, New Brunswick, New Jersey, DOE/OR/21949-380, Oak Ridge, Tenn., Jan.

BNI: See Bechtel National, Inc.

Orlandini, K., 1995, unpublished information.

Skinner, K.R., 1995, personal communication from Skinner (Bechtel National, Inc., Oak Ridge, Tenn.) to D.E. Dunning (Argonne National Laboratory, Oak Ridge, Tenn.), May 18.

Yu, C., et al., 1993a, Manual for Implementing Residual Radioactive Material Guidelines Using RESRAD, Version 5.0: Working Draft for Comment, ANL/EAD/LD-2, Argonne National Laboratory, Argonne, Ill., Sept.

Yu, C., et al., 1993b, Data Collection Handbook to Support Modeling the Impacts of Radioactive Material in Soil, ANL/EAIS-8, Argonne National Laboratory, Argonne, Ill., April. 